\title{
Study of Site Specific Nutrients Management of Cowpea Seed Production and Their Effect on Soil Nutrient Status
}

\author{
Anil Kumar Singh ${ }^{1}$, B. P. Bhatt ${ }^{1}$, P. K. Sundaram ${ }^{1}$, Santosh $\operatorname{Kumar}^{1}$, R. C. Bahrati ${ }^{1}$, Naresh Chandra ${ }^{1} \&$ Mathura Rai ${ }^{2}$ \\ ${ }^{1}$ ICAR Research Complex for Eastern Region, Patna, Bihar, India \\ ${ }^{2}$ Ex. Director, Indian Vegetable Research Institute, Varanasi, Uttar Pradesh, India \\ Correspondence: Anil Kumar Singh, ICAR Research Complex for Eastern Region, Patna 800014, Bihar, India. \\ E-mail: anil.icarpat@gmail.com
}

Received: June 17, 2012 Accepted: June 30, 2012 Online Published: August 31, 2012

doi:10.5539/jas.v4n10p191 URL: http://dx.doi.org/10.5539/jas.v4n10p191

\begin{abstract}
s
To produce anticipated output of any crop, the site specific nutrients management (SSNM) is essential for balance and adequate nutrients supply without impairing the inherent fertility status of soil. For cowpea seed production and to maintain soil nutrient status, a field experiment was conducted with nine treatments (nutrients combinations) to find out appropriate SSNM practice. Nutrients especially N, P, K, S, Zn and Bo requirement for cowpea seed production was estimated to 30,60,50,30, 15 and $2.0 \mathrm{~kg}$ per hectare respectively and treated as $100 \%$ of SSNM. Growth and development parameters were significantly influenced with the treatments. Maximum plant height $(61.9 \mathrm{~cm})$ was recorded when crop was fed with 125 per cent of SSNM. However minimum plant height $(54.8 \mathrm{~cm})$ was recorded in case of SSNM-N. Leaf Area Index (LAI) at 60 DAS ranged from 3.37 to 3.91 . Nodules dry weight was significantly influenced by boron treatments apart from nitrogen and other as well. Maximum seed yield was obtained $(2237.2 \mathrm{~kg} / \mathrm{ha})$ in the plot fertilized with 125 per cent of SSNM and minimum $(1343.5 \mathrm{~kg} / \mathrm{ha})$ was recorded in the plot fertilized with state recommendation. Highest and lowest gross (₹40270/- and ₹ 24183/-) was recorded with 125 per cent of SSNM and with state recommendation respectively. Application of 125 per cent of SSNM recorded maximum uptake of nitrogen $(205.3 \mathrm{~kg} / \mathrm{ha}) \mathrm{which}$ is at par with $100 \%$ of SSNM. None of the treatment influences significantly soil fertility and physico-chemical properties of the soil rather slight improvement were recorded in all the observed parameters though considerable build-up of available $\mathrm{P}$ and exchangeable $\mathrm{K}$ was noticed in plots fertilized with SSNM.
\end{abstract}

Keywords: Cowpea, nutrient management, seed yield, soil nutrient status, SSNM, Vigna unguiculata L.

\section{Introduction}

Cowpea (Vigna unguiculata L.) is a poor's men's protein source. It is one of the most ancient human food sources and has been probably used as a crop plant since Neolithic times ( Ng \& Marechal, 1985). It is an important multipurpose grain legume extensively cultivated in arid and semiarid tropics. It is an important source of nutrients and provides high quality, inexpensive protein to diets based on cereal grains and starchy foods. Cowpea is a good source of food, forage, fodder, vegetable and certain snacks (Nirmal et al., 2001). It is crop of low and high rainfall regions, an important component of cropping system grown as catch crop, mulch crop, intercrop, mixed crop and green crop. It has ability to fix atmospheric nitrogen in soil at the rate of $56 \mathrm{~kg}$ per ha in association with symbiotic bacteria under favourable conditions (Eke et al., 1999; Ahlawat \& Shivkumar, 2005; Fatokum et al., 2000). The mature cowpea seed contains 24.8 per cent protein, 63.6 per cent carbohydrate, 1.9 per cent fat, 6.3 per cent fiber, 0.00074 per cent thiamine, 0.00042 per cent Riboflavin and 0.00281 per cent Niacin (Shaw, 2007). The protein concentration ranges from about 3 to 4 per cent in green leaves, 4 to 5 per cent in immature pods and 25 to 30 per cent in mature seeds. The amino acid profile reveals that lysine, leucine and phenylanine contents are relatively high in cowpea (Anonymous, 2004). Its origin and subsequent domestication is associated with pearl millet and sorghum in Africa. Cowpea cultivation is at least 5000 to 6000 years old (Vavilov, 1951). As per the record, first symptom of cultivation was found in West Africa where it was closely associated with the cultivation of sorghum and pearl millet ( $\mathrm{Ng} \&$ Marechal, 1985). Trend in the production of pulses had adversely affected the per capita availability of pulses. In India per capita/day availability of pulses had decreased from $69 \mathrm{~g}$ during sixties to $35 \mathrm{~g}$, as against the FAO / WHO's current recommendation of 80 grams per day (Ali \& Gupta, 2012). Cowpea originated in Africa and is widely grown in Africa, Latin America, and South East Asia and in the southern United 
States (FAO, 2010; Fatokum et al., 2000; Shaw, 2007). The largest producer is Africa, with Nigeria and Niger predominating, however Brazil, Haiti, India, Myanmar, Sri Lanka, Australia, Bosnia and Herzegovina also have significant production. Worldwide cowpeas are cultivated in approximately 8 million hectares. Area under cowpea in India is 3.9 million hectares with a production of 2.21 million tonnes with the national productivity of $683 \mathrm{~kg}$ per ha. Productivity of cowpea in the state of Bihar is further low $(591 \mathrm{~kg} / \mathrm{ha})$ than national average (Mandal et al., 2009; Ahlawat \& Shivkumar, 2005).

This clearly indicates the necessity to identify the reasons for such low productivity in India in general and Bihar in particular. To improve the production and productivity of cowpea, an experiment was conducted to gauge the magnitude of improvement in cowpea seed production due to added nutrients. The site specific nutrients management (SSNM) is technique to feed the crop via soil to achieve targeted production in location specific soil and agroclimatic condition. The criteria are based on balance and adequate nutrients supply of essential minerals with an objective to at least sustain soil fertility status if not building gradually. Hence, soil test based site specific nutrient management (SSNM) is basic philosophy behind this experiment to feed cowpea crop to realize its potential.

\section{Materials and Methods}

The field experiment was conducted at Crop Research Programme, Pusa, Bihar, India ( $25.98^{\circ} \mathrm{N}$ Latitude, $85.67^{\circ} \mathrm{E}$ Longitude) during 2006 and 2007. The soil of experimental site was sandy loam in texture, calcareous in nature and slightly alkaline in reaction having $\mathrm{pH} 7.6$, EC $0.44 \mathrm{ds} / \mathrm{m}$, Organic carbon $0.42 \%$, available phosphorus 22.7 $\mathrm{kg} / \mathrm{ha}$, exchangeable K $132.5 \mathrm{~kg} / \mathrm{ha}$, zinc $1.6 \mathrm{~kg} / \mathrm{ha}$ and Boron $0.07 \mathrm{~kg} / \mathrm{ha}$. Thus the inherent nutrient supplying capacity of the soil was in the medium range in respect to above mentioned nutrients (Velayutham \& Bhattacharya, 2006). The treatments were organized in complete randomized block design (CRBD) with four replications. Sowing operations were carried out during first week of July 2006 and in first week of November 2006. Seeds were sown on well prepared flat bed at $45 \mathrm{~cm}$ row to row and $30 \mathrm{~cm}$ plant to pant spacing respectively. The size of plots was $2.7 \mathrm{~m} \mathrm{X} 3.0 \mathrm{~m}$. Standard package of practice were adopted as in case of cowpea crops in respect to weed and water management. In general no incidence of disease and pest were recorded during both the season. To improve seed production of cowpea crop, soil test based site specific nutrients management (SSNM) system was planned as discussed earlier, to feed cowpea crop premeditated for seed production. It was found that soil test based requirement of nitrogen $(\mathrm{N})$, phosphorus $\left(\mathrm{P}_{2} \mathrm{O}_{5}\right)$, potassium $\left(\mathrm{K}_{2} \mathrm{O}\right)$, sulphur $(\mathrm{S})$, zinc $(\mathrm{Zn})$ and boron $(\mathrm{Bo})$ are $30,60,50,30,15$ and $2.0 \mathrm{~kg}$ per hectare respectively (Mandal et al., 2009). Bihar State recommendation for cowpea crop is also in similar fashions but restricted to major nutrients only i.e. nitrogen $(\mathrm{N})$, phosphorus $\left(\mathrm{P}_{2} \mathrm{O}_{5}\right)$, potassium $\left(\mathrm{K}_{2} \mathrm{O}\right)$ are @ 30, 60, $50 \mathrm{~kg}$ per hectare respectively. On the basis of above recommendation SSNM was planned to feed cowpea and total nine treatment combinations were tested (Table1). Treatment combinations were made by keeping out of particular nutrient form SSNM and 125 per cent of SSNM. State recommendation was used to compare the SSNM. Sources of nutrient supply were Urea and Di Ammonium Phosphate for Nitrogen, Di Ammonium Phosphate and Single Super Phosphate for Phosphorus, Muriate of Potash for Potassium, Zinc Sulphate for Zinc and Borax for Boron. Zinc Sulphate and Borax contains 20 and 10 per cent Zinc and Boron respectively. Two numbers of irrigation were given at grand growth phase and pre flowering stages during both the seasons. One hand weeding was carried out at initial stage of crop growth. Germinations of seeds were satisfactory during both the season hence crop stand was normal. Weather condition of Pusa, Bihar, was within the range during the experimentation period of both seasons. Experimental soil and plant samples were analysed at Hi Tech Soil and Plant Lab of ICAR Research Complex for Eastern Region, Central facility, Patna, India.

Soil samples were analysed for $\mathrm{pH}, \mathrm{EC}(\mathrm{dSm} / \mathrm{M})$, OC (\%), water holding capacity, Available $\mathrm{P}(\mathrm{Kg} / \mathrm{ha})$ and Exchangeable $\mathrm{K}(\mathrm{Kg} / \mathrm{ha})$ before sowing the experimental crop and after the harvest of each crop cycle to know the influence of cowpea and nutrient management practices on soil physico-chemical parameter, altogether contributing to soil fertility and ultimately productivity of soil (Jackson, 1967). Five plants were selected at random from the inner rows of each plot at 60 days after sowing to determine the growth and its components. Plants were excised at ground level for separation into above ground (leaves, stems and reproductive organs) and below ground portions (roots). To remove soil particles and plant debris from the root surface, the below ground portion was washed carefully under tap water. Leaves, stems, reproductive organs and roots were oven-dried at 70 ${ }^{\circ} \mathrm{C}$ for 72 hours and their dry weights were measured. 
Table 1. Treatments of the experiment

\begin{tabular}{lll}
\hline SI No & Treatment description & Symbol used \\
\hline 1. & Site specific nutrients management (SSNM) & $\mathrm{T}_{1}$ \\
2. & SSNM -Nitrogen & $\mathrm{T}_{2}$ \\
3. & SSNM -Phosphorus & $\mathrm{T}_{3}$ \\
4. & SSNM - Potassium & $\mathrm{T}_{4}$ \\
5. & SSNM -Sulphur & $\mathrm{T}_{5}$ \\
6. & SSNM -Zinc & $\mathrm{T}_{6}$ \\
7. & SSNM -Boron & $\mathrm{T}_{7}$ \\
8. & 125\% of SSNM & $\mathrm{T}_{8}$ \\
9. & State recommendation (Bihar) & $\mathrm{T}_{9}$ \\
\hline
\end{tabular}

Leaf areas were measured for each plant with the help of leaf area meter. Data were recorded on growth, yield attributes and yield and as per requirements converted $\mathrm{Kg} / \mathrm{ha}$. At harvest, nutrient content on whole plant basis was also estimated to calculate nutrient removal by cowpea on per hectare basis for nitrogen, phosphorus, potassium, sulphur, zinc and boron.Observation on days to first flowering was recorded to know the effects of genotypes and environmental condition being a polygenic trait. Plant height $(\mathrm{cm})$, branches (No / plant) Dry matter (g/plant) Leaf area index, nodule dry weight $(\mathrm{g} / \mathrm{plant})$, pod length $(\mathrm{cm})$, biological yield $(\mathrm{kg} / \mathrm{ha})$, seed yield $(\mathrm{kg} / \mathrm{ha})$ and harvest Index was recorded and computed at harvest. For yield attributes, observations were recorded for ten plant sample. To know the economic viability of the developed technology and to test the feasibility and economic sustainability of this entrepreneurship (cowpea seed production) an economics analysis based on cost of cultivation, gross return, net return and benefit cost $(\mathrm{B}: \mathrm{C})$ ratio has been carried out (Kishan et al., 2002).

$$
\text { BC Ratio }=\frac{\text { Gross Return }(z)}{\text { Total } \operatorname{cost}(z)}
$$

Pooled analysis was carried out as per normal procedures. The analysis of variance was carried out for the results and treatment means were separated using the least significant difference (LSD) according to the procedure described by Gomez and Gomez (1984).

\section{Results and Discussion}

Observations taken and simultaneously data were recorded and subjected to statistical analyses and presented in appropriate format in the tables. Results obtained are being discussed under following sub heads.

\subsection{Effects of Nutrient Management on Growth and Developments}

Site specific nutrients management (SSNM) had influenced the growth and development activities of all parameter under studies. Growth and development (vegetative phase) stage play crucial role and set a stage for proper execution of reproductive phase to produce excellent economic yield in terms of seeds (Anonymous, 2004; Ramamurthy et al., 1990; Singh, 2003). Being legume crop, it is in general indeterminate in habit; however due to breeding efforts some of intermediate type has also developed and this variety also belong to the intermediate growth habit ( $\mathrm{Ng} \&$ Marechal, 1985; Chaturvedi et al., 1980). Plant height $(\mathrm{cm})$ is one of the important growth and development feature of any crop commodity, on which other component like leaves, flowers and pod follows. Perusal of data presented in Table 2 revealed that stature of plant influenced with all the treatments under test. Plant build-up was drastically reduced $(54.8 \mathrm{~cm})$ due to absence of nitrogen nutrient despite of others are present at optimum level in case of "SSNM-N" treatment combination. This result also indicates importance of nitrogen in the vegetative growth phase. Maximum plant height $(61.9 \mathrm{~cm})$ was recorded when crop was fed with 125 per cent of SSNM dose. Similar results were also reported by Ahlawat and Shivkumar, 2005 and Mandal et al., 2009. To know effects of nutrient management practices on the branching behaviour, branches were counted at 60 days after sowing of cowpea crop. Though it is one of characters closely associated with genetic makeup, it was significantly influenced with the nutrient management practices. Minimum branching (9.7/plant) was reported with "SSNM-N" treatment; whereas corresponding higher branching (12.2) was recorded with treatment "125 per cent of SSNM". Similarly other growth and development parameters were also influenced with the applied treatments. Results obtained from respective experimentation by Ramamurthy et al., 1990 and Mandal et al., 2009 were in accordance with these findings. Dry matter (g/plant) was recorded at a peak active growth stages (60 DAS) and it ranged from 35.7 to 48.3. Data on dry matter accumulation provide positive indication about photosynthetic efficiency of a particular genotype with the 
offered environmental condition and agronomic management practices. Leaf Area Index (LAI) was also worked out at 60 DAS to know the ratio between leaf areas produced by crop in relation to land area occupied by them. Presence of higher LAI is due to more leaf per unit area. It was noticed that it ranges from 3.37 to 3.91. Gandhi et al., 1991 and Chowdhury, 2000 also reported alike trend. Nodules dry weight (g/plant) at 60 DAS was also recorded to know the effectiveness and efficiency of applied treatments for producing efficient nodules which can contribute positively to nitrogen economy of crops in its life span and later on to help build-up of inherent soil fertility status. It was found that applied treatments have influenced nodules production significantly (Table 2). Nodules dry weight was significantly influenced by boron treatments apart from nitrogen and other as well. These finding is in the order of Chowdhury, 2000; Gracy et al., 1998; Kishan et al., 2002.

Table 2. Cowpea growth and development influenced by different treatments

\begin{tabular}{|c|c|c|c|c|c|}
\hline Treatments & $\begin{array}{l}\text { Plant height }(\mathrm{cm}) \\
\text { at maturity }\end{array}$ & $\begin{array}{l}\text { Branches } \\
\text { at } 60 \text { DAS } \\
\text { (No/plant) }\end{array}$ & $\begin{array}{l}\text { Dry matter } \\
(\mathrm{g} / \text { plant }) \text { at } 60 \mathrm{DAS}\end{array}$ & $\begin{array}{l}\text { Leaf Area Index } \\
(\mathrm{LAI}) \text { at } 60 \mathrm{DAS}\end{array}$ & $\begin{array}{l}\text { Nodules dry } \\
\text { weight (g/plant) } \\
\text { at } 60 \mathrm{DAS}\end{array}$ \\
\hline SSNM & 60.7 & 11.6 & 45.2 & 3.81 & 5.21 \\
\hline SSNM -Nitrogen & 54.8 & 9.7 & 35.7 & 3.37 & 3.91 \\
\hline SSNM -Phosphorus & 56.8 & 10.5 & 36.8 & 341 & 5.14 \\
\hline SSNM - Potassium & 57.3 & 10.9 & 37.7 & 3.48 & 4.63 \\
\hline SSNM -Sulphur & 58.1 & 11.3 & 39.4 & 3.65 & 4.27 \\
\hline SSNM -Zinc & 59.2 & 11.8 & 38.7 & 3.61 & 5.08 \\
\hline SSNM -Boron & 58.4 & 10.1 & 38.1 & 3.52 & 4.42 \\
\hline $125 \%$ of $\mathrm{SSNM}$ & 61.9 & 12.2 & 48.3 & 3.91 & 5.31 \\
\hline State recommendation & 57.9 & 10.4 & 40.8 & 3.78 & 5.06 \\
\hline $\mathrm{CD}(5 \%)$ & 4.3 & 0.7 & 4.6 & 0.34 & 0.71 \\
\hline
\end{tabular}

\subsection{Effects of Nutrient Management on Yield Attributes and Seed Yield}

Perfect completion of vegetative growth phase is indication of better seed production which again depends upon several factors. Some of reproductive parameters also initiate in conjunction with later stage of vegetative phase viz., days taken to first flowering, being not a perfect determinant in its growth pattern. Days taken to first flowering get influenced with applied nutrient management treatments (Table 3). An early onset of flowering is a positive indication, provide enough and extra time for seed formation and production activities. Early onset of anthesis (first flowering) was noticed with balance nutrient application, extra early flowering was recorded (36.3 days) with 125 per cent of SSNM dose. These findings are in close conformity with the results of Mandal et al., 2009; Singh and 2003 Singh et al., 2006. Results shows that maximum time taken (41.5 days) for onset of anthesis was with "SSNM - - zinc", this might be due to its role in stimulation of flowering hormones. Similar trend was also noticed in case of "SSNM-P" treatment (Table 3). Pod length, is a traits closely associated with its genetic makeup, get influenced significantly with applied treatments. Longest pod $(31.2 \mathrm{~cm})$ was obtained with 125 per cent of SSNM dose, however shortest one $(27.5 \mathrm{~cm})$ was noticed in case of treatment "SSNM - N". Workers like Baboo and Mishra, 2001; Bhilare and Patil, 2002 also find similar trends while experimenting at their respective places. Biological yield is sum total of biomass produce by the plant under given circumstance, it also denotes the photosynthetic efficiency of particular genotype and source -sink relationship. Total biomass production has also been influenced with tested treatments (Table 3). Optimum (SSNM) application of nutrient produced significantly higher Biological yield $(3206.5 \mathrm{~kg} / \mathrm{ha})$ than other tested nutrient management treatments but produced significantly lower $(3441.5 \mathrm{~kg} / \mathrm{ha})$ than obtained with 125 per cent of SSNM dose. Minimum Biological yield (2317.2 kg/ha) was obtained in case of State recommendations. Bhagawandas et al., 1997; Fatokum et al., 2000 and Gandhi et al., 1991 are also reported equivalent results in their respective investigations. Cowpea seed yield was influenced with the treatment combination applied to them. As in case of other growth \& development traits, yield contributors, significantly maximum seed yield $(2237.2 \mathrm{~kg} / \mathrm{ha})$ was recorded with 25 per cent extra application of nutrient over optimum dose (SSNM). SSNM produced significantly higher seed $(1972.4 \mathrm{~kg} / \mathrm{ha}$ ) than other tested treatment but lower than 125 per cent of SSNM (Table 3). "SSNM-N" treatment application proves costly also for seed yielding capability by producing least (1406.8 $\mathrm{kg} / \mathrm{ha}$ ). Harvest Index (HI) is very less influenced by management practices being related to genotype architect. However nutrient management practices influenced HI significantly. Minimum HI was obtained (0.58) with state recommendations and "SSNM-N" treatment. Maximum HI (0.62) was recorded with SSNM. The results 
obtained in this experiment is in the accordance of results of Gracy, et al., 1998; Ahlawat and Shivkumar, 2005 and Mandal et al., 2009.

Table 3. Cowpea yield attributes and yield

\begin{tabular}{llllll}
\hline Treatments & $\begin{array}{l}\text { Days to } \\
\text { first flowering }\end{array}$ & $\begin{array}{l}\text { Pod length } \\
(\mathrm{cm})\end{array}$ & $\begin{array}{l}\text { Biological yield } \\
(\mathrm{Kg} / \mathrm{ha})\end{array}$ & $\begin{array}{l}\text { Seed yield } \\
(\mathrm{Kg} / \mathrm{ha})\end{array}$ & $\begin{array}{l}\text { Harvest } \\
\text { Index }\end{array}$ \\
\hline SSNM & 38.5 & 30.5 & 3206.5 & 1972.4 & 0.62 \\
SSNM -Nitrogen & 39.5 & 27.5 & 2417.2 & 1406.8 & 0.58 \\
SSNM -Phosphorus & 40.1 & 28.4 & 2552.4 & 1495.7 & 0.59 \\
SSNM - Potassium & 37.8 & 29.7 & 2649.2 & 1568.3 & 0.59 \\
SSNM -Sulphur & 38.1 & 29.5 & 2715.1 & 1637.2 & 0.60 \\
SSNM -Zinc & 41.5 & 29.8 & 2818.8 & 1705.4 & 0.60 \\
SSNM -Boron & 39.3 & 29.1 & 2670.4 & 1596.9 & 0.61 \\
125\% of SSNM & 36.3 & 31.2 & 3441.5 & 2237.2 & 0.65 \\
State recommendation & 38.5 & 28.5 & 2317.2 & 1343.5 & 0.58 \\
CD (5\%) & 2.1 & 1.8 & 147.2 & 123.8 & 0.03 \\
\hline
\end{tabular}

\subsection{Effects of Nutrient Management on Economics of Cowpea Cultivation}

An effort has been made to calculate cost of cowpea seed production to evaluate the economic feasibility of developed technology. Data on cost calculation is depicted in Table 4. The total cost is made-up of fixed cost and running cost. Fixed cost (₹8000/-) is for leasing out one hectare land which is same for all the treatments. Running cost is actual cost which is variable according to treatment requirements (Table 1). In running cost all cost including weed management, water management, plant protection measure, harvesting, threshing etc are included. Gross returns is the income generated after selling of cowpea seed @ ₹ $18 / \mathrm{kg}$, whereas net return is the sole income generated after deducting all the expenses incurred. Highest and lowest gross (₹40270/- \& ₹ 24183/-) and corresponding highest and lowest net return (₹22295/- \& ₹9453/-) was recorded with 125 per cent application of SSNM and with state recommendation (Table 4). Benefit cost ratio (BC ratio) is the ratio between benefit gain and cost paid or gains in rupees of per rupee investment. The maximum BC ratio (2.24) was obtained with nutrient application 125 per cent of SSNM dose, corresponding minimum value (1.61) was recorded with "SSNM-N" treatment. The above findings were also supported by Kishan et al., 2002; Singh, et al., 2006 and Mandal et al., 2009.

Table 4. Economics of cowpea cultivation

\begin{tabular}{lllllll}
\hline & \multicolumn{2}{l}{ Cost of cultivation (₹/ha) } & & & \\
\cline { 2 - 5 } Treatments & Fixed / Land cost & Running cost & Total cost & Gross return (₹) & Net Return( ₹) & BC Ratio \\
\cline { 2 - 6 } SSNM & 8000 & 7980 & 15980 & 35503 & 19523 & 2.22 \\
SSNM -Nitrogen & 8000 & 7740 & 15740 & 25322 & 9582 & 1.61 \\
SSNM -Phosphorus & 8000 & 7260 & 15260 & 26923 & 11663 & 1.76 \\
SSNM - Potassium & 8000 & 7620 & 15620 & 28229 & 12609 & 1.81 \\
SSNM -Sulphur & 8000 & 7380 & 15380 & 29470 & 14090 & 1.92 \\
SSNM -Zinc & 8000 & 7530 & 15530 & 30697 & 15167 & 1.98 \\
SSNM -Boron & 8000 & 7780 & 15780 & 28744 & 12964 & 1.82 \\
125\% of SSNM & 8000 & 9975 & 17975 & 40270 & 22295 & 2.24 \\
State recommendation & 8000 & 6730 & 14730 & 24183 & 9453 & 1.64 \\
\hline
\end{tabular}

\subsection{Effects of Nutrient Management on Nutrient Uptakes by Cowpea}

Nutrient balance sheet has been prepared to know the effect of nutrient management practices. Perusal of table 5 clearly vindicates that nitrogen uptake by crop is directly associated with the applied nutrients. Optimum application of nutrients (SSNM) proves significantly higher removal of nitrogen $(196.3 \mathrm{~kg} / \mathrm{ha})$, by crop which is at par with 125 per cent SSNM dose (Table 5). Significant lower uptake of nitrogen $(137.8 \mathrm{~kg} / \mathrm{ha}$ ) was recorded with "SSNM -N" dose of nutrients. Similar trend was also prevailed in the uptake of other applied nutrients. Identical manner of uptake was also reported by Eke et al., 1999; Fatokum et al., 2000 and Singh, et al., 2006. It is worth mentioning that least uptake of phosphorus $\left(\mathrm{P}_{2} \mathrm{O}_{5}\right)$ was noticed also in case with no application of 
nitrogen $(14.3 \mathrm{~kg} / \mathrm{ha})$. Maximum phosphorus uptake $(31.3 \mathrm{~kg} / \mathrm{ha})$ was recorded with 125 per cent of SSNM treatment. Maximum $(161.4 \mathrm{~kg} / \mathrm{ha})$ and minimum $(97.4 \mathrm{~kg} / \mathrm{ha})$ uptake of Potassium $\left(\mathrm{K}_{2} \mathrm{O}\right)$ was registered in case of with 125 per cent of SSNM treatment and non-application of nitrogen nutrition (SSNM-N). Sulphur uptake range minimum $(8.9 \mathrm{~kg} / \mathrm{ha})$ in case of "SSNM-N" to Maximum $(28.3 \mathrm{~kg} / \mathrm{ha}), 1125$ per cent of SSNM application. Analogous results were also noticed in case of zinc and boron uptake by cowpea crop (Table 5). Similar type of trend were also reported by Gracy, et al., 1998; Chowdhury et al., 2000; Baboo et al., 2001 and Bhilare and Patil, 2002.

Table 5. Nutrient uptakes $(\mathrm{Kg} / \mathrm{ha})$ by cowpea

\begin{tabular}{lllllll}
\hline Treatments & $\begin{array}{l}\text { Nitrogen } \\
(\mathrm{N})\end{array}$ & $\begin{array}{l}\text { Phosphorus } \\
\left(\mathrm{P}_{2} \mathrm{O}_{5}\right)\end{array}$ & $\begin{array}{l}\text { Potassium } \\
\left(\mathrm{K}_{2} \mathrm{O}\right)\end{array}$ & $\begin{array}{l}\text { Sulphur } \\
(\mathrm{S})\end{array}$ & $\begin{array}{l}\text { Zinc } \\
(\mathrm{Zn})\end{array}$ & $\begin{array}{l}\text { Boron } \\
(\mathrm{Bo})\end{array}$ \\
\hline SSNM & 196.3 & 29.6 & 151.3 & 26.3 & 0.81 & 0.86 \\
SSNM -Nitrogen & 137.8 & 14.3 & 97.4 & 8.9 & 0.34 & 0.61 \\
SSNM -Phosphorus & 145.2 & 16.7 & 105.7 & 11.4 & 0.43 & 0.72 \\
SSNM - Potassium & 156.8 & 18.2 & 112.4 & 14.4 & 0.49 & 0.75 \\
SSNM -Sulphur & 160.4 & 20.5 & 116.3 & 17.3 & 0.53 & 0.79 \\
SSNM -Zinc & 165.7 & 22.4 & 125.9 & 18.9 & 0.57 & 0.81 \\
SSNM -Boron & 171.8 & 24.1 & 131.7 & 22.7 & 0.61 & 0.69 \\
125\% of SSNM & 205.3 & 31.3 & 161.4 & 28.3 & 0.87 & 0.91 \\
State recommendation & 183.3 & 27.4 & 145.2 & 24.9 & 0.74 & 0.77 \\
CD (5\%) & 17.3 & 3.9 & 32.9 & 3.2 & 0.21 & 0.12 \\
\hline
\end{tabular}

\subsection{Effects of Nutrient Management on Soil Properties}

To ascertain the extent and pattern of influence of nutrient management treatments on soil physical and chemical properties in combination with cowpea this study was undertaken and results were presented in Table 6. Perusal of data shows that none of treatment influences significantly the soil $\mathrm{pH}$, electrical conductivity (EC), water holding capacity and organic carbon content (OC \%). There is significant build-up of available $\mathrm{P}$ and exchangeable K with the applied treatments (Table 6). Minimum Phosphorus (34.1 kg/ha) build up was recorded with "SSNM-P" treatment and corresponding maximum $(34.1 \mathrm{~kg} / \mathrm{ha})$ was obtained with maximum application of nutrients (125 per cent of SSNM). Alike results was noticed in case of build-up of exchangeable K. Minimum K $(147.2 \mathrm{~kg} / \mathrm{ha})$ build up was recorded with "SSNM-K" and corresponding maximum $(156.3 \mathrm{~kg} / \mathrm{ha})$ was obtained with 125 per cent of SSNM treatment. Similar kind of trends were also reported by Chowdhury et al., 2000; Baboo et al., 2001; Bhilare and Patil, 2002 and Kishan et al., 2002.

Table 6. Soil properties influences by cowpea

\begin{tabular}{lclllll}
\hline \multirow{2}{*}{ Treatments } & $\mathrm{pH}$ & $\begin{array}{l}\mathrm{EC} \\
\mathrm{dSm} / \mathrm{M}\end{array}$ & $\begin{array}{l}\text { WHC } \\
(\%)\end{array}$ & $\begin{array}{l}\text { OC } \\
(\%)\end{array}$ & $\begin{array}{l}\text { Available P } \\
(\mathrm{Kg} / \mathrm{ha})\end{array}$ & $\begin{array}{l}\text { Exchangeable K } \\
(\mathrm{Kg} / \mathrm{ha})\end{array}$ \\
\cline { 2 - 7 } SSNM & 8.2 & 0.25 & 38.7 & 0.57 & 37.2 & 153.6 \\
SSNM -Nitrogen & 8.4 & 0.24 & 39.7 & 0.56 & 35.7 & 156.8 \\
SSNM -Phosphorus & 8.3 & 0.25 & 40.5 & 0.58 & 34.1 & 153.7 \\
SSNM - Potassium & 8.4 & 0.23 & 39.9 & 0.56 & 36.4 & 147.2 \\
SSNM -Sulphur & 8.5 & 0.24 & 39.4 & 0.55 & 35.2 & 158.2 \\
SSNM -Zinc & 8.5 & 0.26 & 38.5 & 0.56 & 36.1 & 155.6 \\
SSNM -Boron & 8.4 & 0.24 & 39.1 & 0.54 & 35.7 & 154.2 \\
125\% of SSNM & 8.3 & 0.23 & 39.4 & 0.57 & 38.1 & 156.3 \\
State recommendation & 8.2 & 0.24 & 39.9 & 0.55 & 35.7 & 148.2 \\
CD (5\%) & NS & NS & NS & NS & 1.5 & 3.4 \\
\hline
\end{tabular}




\section{Summary}

Soil test based site specific nutrient management (SSNM) produced cowpea seed $1972.4 \mathrm{~kg} / \mathrm{ha}$. Higher dose (125 per cent of SSNM) is advocated to reap further more $(2237.2 \mathrm{Kg} / \mathrm{ha})$, this is also supported by highest BC ratio (2.24). Moreover, application of nutrients as per state recommendation produces cowpea seed @ $1343.5 \mathrm{~kg} / \mathrm{ha}$ only. Nitrogen proves to be significant contributor to the growth, development and finally seed yield, as it is evident from the study. Application of sulphur, zinc and boron contributed significantly. In view of soil health and its sustainability, application of 25 per cent above optimum nutrients (SSNM) did not show any detrimental effects, rather improved it. Requirement of higher dose (125 per cent of the SSNM) might be due to extra energy which is required for successfully alleviation of the negative influence on its seed producing abilities due to inadequate or interpreted supply of nutrient when it matters more. These inabilities of soil may due to physical, chemical and biological hindrance. Based on above findings, it is advocated that nutrient management with optimum (SSNM) or 125 per cent of SSNM is remunerative for cowpea seed production. Further this technology is very much financially viable as well as sustainable on soil health ground.

\section{References}

Ahlawat, I. P. S., \& Shivkumar, B. G. (2005). Kharif Pulses. In Text book of field crops production. Dr. Rajendra Prasad (eds.) Indian Council of Agriculture research, New Delhi, India.

Ali, M., \& Gupta, S. (2012) .Carrying capacity of Indian agriculture: pulse crops. Cur. Sci., 102(6), 874-881.

Anonymous. (2004). Annual Report, Indian Institute of Vegetable Research, Varanasi.

Baboo, R., \& Mishra, S. K. (2001). Growth and pod production of cowpea (Vigna sinensis L.) as affected by inoculation, nitrogen and phosphorus. Annals of Agricultural Research, 22, 104-106.

Bhagawandas, Shedran, R. S., \& Das, B. (1997). Effect of phosphorus fertilization on quality and yield of cowpea. Annals of Biology, 13, 195-196.

Bhilare, R. L., \& Patil, V. S. (2002). Response of forage cowpea varieties to phosphorus application. Forage Research, 28, 179-180.

Chaturvedi, G. S., Agarwal, P. K., \& Singh, S. K. (1980). Growth and yield of determinate and indeterminate cowpeas in dry land agriculture. Journal of Agricultural Science, 94, 137-144. http://dx.doi.org/10.1017/S0021859600027982

Chowdhury, M. M. U., Ullah, M. H., Rahman, M. A., \& Shahdunslam, M. (2000). Effect of boron and nitrogen fertilization on cowpea growth, nodulation and grain yield in Rangamati, Bangladesh. Legume Research, 23, 9-14.

Eke, Okor, O. N., Ikeorgu, J. E. G., \& Okorocha, E. O. A. (1999). Comparative evaluation of five legume species for soil fertility improvement, weed suppression and component crop yields in Cassava / legume intercrops. Afric. J. Roots and Tuber crops, 3, 17-54.

FAOSTAT. (2010). Food and Agriculture Organization of the United Nations. Rome, Italy. (http://www.faostat.fao.org).

Fatokum, C. A., Taarawale, S. S., Singh, B. B., Korimawa, P. M., \& Tamo, M. (2000). Challenges and opportunities for enhancing sustainable cowpea production. Proc. of the world cowpea conference III held at IITA Ibadan, Nigeria 4-8 September 2000, pp. 214-220.

Gandhi, D. V., Wagh, R. G., \& Thorat, S. T. (1991). Effect of sowing times and fertilization on the yield and quality of cowpea. Agricultural Science Digest Karnal, 11, 178-180.

Gomez, K. M., \& Gomez, A. A. (1984). Statistical Procedures for Agricultural Research, Edition 2, John Wiley, New York.

Gracy, M., Sreenivasan, E., Anilkumar, K., \& Mathew, R. (1998). Effect of phosphorus and sulphur on growth and yield and nutrient uptake of rainfed upland cowpea. Journal of Tropical Agriculture, 36, 31-33.

Jackson, M. L. (1967). Soil and Chemical Analysis, Prentice Hall of India, Private Limited, New Delhi.

Kishan, S., Rathore, S. V. S., \& Swaroop, K. (2002). Economics, nutrient content and pod yield of vegetable cowpea in relation to application of $\mathrm{P}, \mathrm{K}$ and Rhizobium biofertilizer in Andaman. Indian Agriculturist, 46, 155-160.

Mandal, M. K., Pati, R., Mukhopadhyaya, D., \& Majumdar, K. (2009). Maximizing yield of cowpea through soil test based nutrient application in Tarai alluvial Soils. Better crop India. pp. 28-30. 
Ng, N. Q., \& Marechal, R. (1985). Cowpea Taxonomy, Origen and germplasm. In Singh RS Rachie KO (Eds) Cowpea research production and utilization. John Wiley and Sons, New York. pp.11-21.

Nirmal, R., Kalloo, G., \& Kumar, R. (2001). Diet versatility in cowpea (Vigna unguiculata) genotypes. Indian Journal of Agricultural Sciences, 71, 598-601.

Ramamurthy, V., Hananagi, E. V., \& Manjappa, H. V. (1990). Response of cowpea to fertilizer and protective irrigation. Indian Journal of Agronomy, 35, 330-331.

Shaw, Monica. (2007-10-28). 100 Most Protein Rich Vegetarian Foods. Smarter Fitter Blog. http://smarterfitter.com/blog/2007/10/28/100-most-protein-rich-vegetarian-foods/. Retrieved 2011-11-11.

Singh, B. (2003). Improving the production and utilization of cowpea as food and fodder. Field Crops Research, 84, 169-150. http://dx.doi.org/10.1016/S0378-4290(03)00148-5

Singh, N., Rai, M., Singh. B, Singh, M., \& Pandey, S. (2006). Frontline Demonstration of improved varieties of vegetable crops, Indian Horticulture, ICAR, New Delhi, May-June.

Vavilov, N. I. (1951).The origin, variation immunity and breeding of cultivated plants. Chronica Botanica, New York. 13-1/ 6:26-38, 75-78 151 (1949-50).

Velayutham, M., \& Bhattacharya, T. (2006). Soils. In Handbook of Agriculture. ICAR New Delhi. pp. 155-181. 